\title{
Polyphenism by the level of predation risk in larval salamander, Hynobius leechii
}

\author{
Jihee Hwnag* Eun-ji Kim* $\cdot$ Ho-Jin Kim* $\cdot$ Hoon Chung**+ \\ * Department of Convergence Science, Sahmyook University, Seoul(139-742), Korea \\ ** Department of Annimal resource, Sahmyook University, Seoul(139-742), Korea
}

포식압 수준에 따른 한국산 도롱농 유생의 표현형의 변화

\author{
황지희* · 김은지* · 김호진* · 정 훈**+ \\ * 삼육대학교 대학원 융합과학과 행동과학연구실 \\ *** 삼육대학교 동물자원학과
}

\begin{abstract}
This study examined the cannibalistic polyphenism of larval salamander Hynobius leechii by the level of predation risk. Salamander eggs were collected from three regions (Mountain Inwang, Mountain Surak and Gwangju). Eggs were treated by three different risk conditions: (1) high risk, predation risk three times a day; (2) medium risk, predation risk once a day; and (3) low risk, no predation risk. Predation risk was conducted using a chemical cue from Chinese minnows. The chemical cue treatment started from the day of collection and ended one week after hatching. Post-treatment measurements were head width at the level of the eyes (HWE), largest head width (LHW), and Snout-vent length of the each larva. To compare the morphological change according to the predation risk, we modified the two head size, HWE and LHW, to HWE/LHW. A significant difference in HWE/LHW and snout-vent length was evident according to the level of predation risk. And larval mortality was increase by the predation risk. The results indicate that predation risk can cause cannibalistic polyphenism of larval salamander and this morphological change could influence larval mortality.
\end{abstract}

Keywords : cannibal morph; cannibalism; chemical cue; Hynobius leechii; Korean salamander; polyphenism

요 약

본 연구는 한국산 도롱농 유생(Hynobius leechii)을 대상으로 포식압의 수준이 카니발리즘적 폴리페니즘에 영향을 미치는 지 알아보기 위하여 수행되었다. 버들치의 냄새를 포식자 신호로 이용하여 (1) 높은 포식압- 하루 세 번의 포식압 (2) 중 간 포식압- 하루 한 번의 포식압 (3) 포식압 없음 세 그룹으로 나누어 채집일로부터 부화 후 일주일까지 처리하였다. 먹 이섭취로 인한 형태적 변화를 막기 위하여 실험은 기아상태에서 진행되었으며, 도롱뇽 유생은 경기도 광주, 인왕산, 수락 산에서 채집된 난괴를 이용하였다. 포식압 처리 이후 도롱뇽 유생의 머리 중 가장 넓은 곳의 길이(LHW), 눈이 있는 부분 의 머리길이(HWE). 그리고 코 끝부터 항문(SVL)까지의 길이를 측정하였다. 카니발리즘적 폴리페니즘의 측정은 $\mathrm{HWE}$ 를 LHW로 나눈 수치(HWE/LHW)를 이용하여 통계처리를 하였고, 그 결과 포식압 수준이 증가함에 따라 HWE/LHW와 SVL 이 유의미하게 증가하는 것을 볼 수 있었다. 또한 각 포압에 따른 사망률을 조사하여 본 결과 포식압 수준에 따른 증가 를 보여, 카니발리즘적 폴리페니즘은 매우 에너지 소모적인 것으로 볼 수 있었다. 이러한 결과를 통하여 도롱농유생은 한 정적 자원을 가진 환경에서 포식압에 의하여 카니발리즘을 일으키기 유리한 형태로 변화할 수 있다는 것을 알 수 있었다

핵심용어 : 카니발리즘 형태, 카니발리즘, 케미컬큐, 한국산 도롱뇽, 폴리페니즘

\section{Introduction}

Polyphenism is the occurrence in a population of alternative phenotypes that are produced from a single genotype in response to different environmental stimuli (West-Eberhard, 1989). It often results in expression of the phenotype that is most advantageous under the prevailing environmental conditions, thereby facilitating an examination of the fitness consequences of different phenotypes (West-Eberhard, 1992). In particular, the presence of discrete phenotypic differences in behavior, morphology, and life history among individuals of a species in relation to cannibalism is known as cannibalistic polyphenism (Polis, 1981; Crump, 1992).

+ Corresponding author : chungh@syu.ac.kr 
Cannibalism is a phenomenon encompassing all or part of a conspecific, which occurs in nearly every major vertebrate and invertebrate group (Elgar and Crespi, 1992). In some species, certain individuals even develop specialized weaponry to facilitate the capture and consumption of conspecifics. For example, tiger salamander larvae (Ambystoma tigrinum) occur in nature as two alternative morphs: a typical morph that feeds mostly on invertebrate prey, and a cannibal morph that has a wider gape, enlarged teeth, and modified oral bones to facilitate the ingestion of conspecifics (Pfenning, 1997). Similar findings have been described in the Hokkaido salamander, Hynobius retardatus, larvae tend to adopt the broad-headed morph form when reared with a scarce food level, high density with others, and mixed sibling groups (Wakahara, 1995). Broad-headed morphs are induced without actual cannibalism and also are induced frequently during the prefeeding stage (i.e., the 5-6 day stage from just after hatching to the initial feeding) (Nishihahra, 1996; Michimae and Wakahara, 2001). In the case of Korean salamanders (Hynobius leechii) larvae prefer to consume live, weak, and small conspecifics and preyed on siblings more often than on non-siblings (Park et al., 2005).

Aquatic animals use chemical information from the environment to make behavioral decisions relating to foraging, reproduction, and assessment of predation risk (Wisenden, 2000). Predation events escalate along a series of steps beginning with initial detection, attack, capture and finally to prey ingestion (Lima and Dill, 1990). At each step in this predation sequence chemical cues are released that can be used by prey to assess and avoid predation risk. In response to these cues, the prey adopts species-specific antipredator behavior. Typically, these involve any or all of the following: reduction in activity, movement out of the water column, seeking shelter, area avoidance, increased shoal cohesion (Wisenden, 2000), and altered morphology (Kats and Dill, 1998; Tollrian and Harvell, 1999).

The present study focused on modification of morphology (polyphenism) as antipredator response of prey. Both size at metamorphosis and the timing of metamorphosis in amphibians affect later fitness through effects on juvenile survival and adult fecundity (Smith, 1987; Berven, 1990; Scott, 1994; Altwegg and Rayver, 2003). In general, phenotypic differences in life-history and morphological traits observed among natural populations reared under experimental conditions may arise from genetic differentiation due to local adaption and drift, or from phenotypic plasticity (Stemberger and Gilbert, 1987; Jackson and Semlitsch, 1993; Van Buskirk and Schmidt, 2000; Merila and Crnokrak, 2001). Furthermore, predator odor is sufficient to initiate at least some components of the morphological defenseof larval amphibians (Van Buskirk and Arioli, 2002). Thus increasing investment in defensive traits entails increasing fitness costs.

Most studies to date have addressed morphological changes at metamorphosis; there has been no research concerning the correlation between predation risk and cannibalistic morphology. For this reason, we conducted a laboratory-based experiment grounded in these empirical facts to test the hypothesis that a high predation risk will prompt the cannibal morph. In the previous study, we found that predation risk and their habitat can cause cannibalistic polyphenism in larval salamander. In the present research, we focused on the polyphenism by the level of predation risk and the odor of chinese minnows was used an as a indirect predator as we used previously. Exposure to predator odor was done 1-3 times daily to establish predator risk levels from the day of collection to one week after hatching. The prey head size was measured and compared between predator risk levels.

\section{MATERIALS AND METHODS}

\subsection{Animal Collection and Environment}

Twenty seven Korean salamander (H. leechii) egg masseswere collected from a stream in Inwang $\left(37^{\circ} 35^{\prime} 58\right.$. $\left.8^{\prime \prime}, 126^{\circ} 58^{\prime} 03^{\prime \prime}\right)$, and small ponds in the Surak $\left(37^{\circ} 40^{\prime} 58\right.$. $\left.1^{\prime \prime}, 127^{\circ} 03^{\prime} 46.3^{\prime \prime}\right)$, and Mountain Gwangju (37 $23^{\prime} 13^{\prime \prime}$, $127^{\circ} 12^{\prime 2} 4^{\prime \prime}$ ) between March 4 and April 3, 2010. In general, Korean salamanders lay their eggs at small ponds, agricultural areas, stone breaks and inlet where the water flow is slower than other parts of stream, or at the center of the stream, which has relatively low fluid speed because of the accumulation of fallen leaves.

In case of Mountain Inwang, thousands of eggs were laid at a stream approximately $1 \mathrm{~km}$ long located in a treed small valley. This region is famous for the mass breeding of salamanders and frogs, which occursnear the civic center every spring.

Except for Mountain Inwang, other two collection points were typical, with each pond being temporary. Egg masses from Mountain Surak were collected at the small pond apart from the main stream and egg massesfrom Gwangju were collected from the small pond. The egg 
masses collected from the three locales were individually stored in a plastic container (29 long $\times 16$ wide $\times 19 \mathrm{~cm}$ high) filled with 31 of dechlorinated tap water. Each container was supplied with air at room temperature. The water temperature in the container ranged between $11-20{ }^{\circ} \mathrm{C}$ throughout the experiment and the photoperiod was not controlled. The test was begun the day following collection. Most eggs hatched approximately 2 weeks after the day of collection during this 2-week period, egg masses comprising 27 eggs were housed in each container for the chemical cue treatment. After hatching, 8-10 larval salamanders were separated from the egg mass and kept in an independent container to prevent larval salamanders from the cannibalism and cannibal morph induction by high density. If, for example, 24 larva hatched from one egg mass, two other test container would each receive eight individuals.

\subsection{Test procedure}

We consulted the study of Brown et al (2006) to determine the predation risk levels. And all test procedure were followed our previous study Hwang and Chung (2010). In detail, three groups of eggs were established for three different predation risks high - predator cue injection three times a day, low -once in a day and no predator cue. Predator cue injection was practiced three times a day at 10:00, 13:00, and 16:00. In case of low predation risk, predator cue injection was conducted at 13:00. Each treatment consisted of addition of $2 \mathrm{ml}$ of a solution of the predator chemical cue extracted from Chinese minnows. Treatment involved injection of the chemical cue along the container wall so as not to disturb the test animals by any generated water waves.

In general, Chinese minnows are omnivorous, and prey on aquatic plants, water beetles, and small larval amphibians. In the stream environment, larval salamanders can be the prey of Chinese minnows, making them as appropriate model to use. We captured three Chinese minnows from the pond in Mountain Bulam and fed them commercial fish flakes every other day. A predator cue was made everyday using $500 \mathrm{ml}$ dechlorinated tap water and one Chinese minnow the minnow was housed overnight as described previously so that the predator's odor could disseminate through the water (Ferrari and Chivers, 2008; 2009). The minnows used as the chemical cue source were changed daily to avoid undue stress on each minnow. Tests were done beginning the day after collection until one week after hatching. At the conclusion of the test, the larval head size and snout-vent length (SVL) of each salamander was measured (Wakahara, 2001). Head width at the level of the eyes (HWE) and the largest head width (LHW) were measured (Fig. 1).

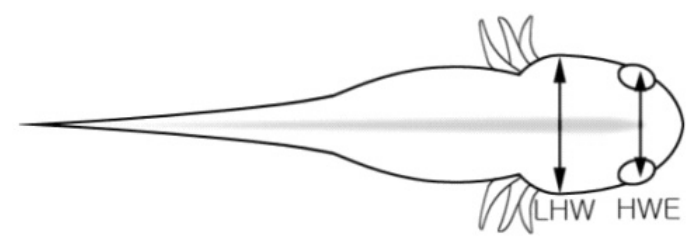

Fig 1. Dorsal projections of landmark locations on experimentally-reared $H$. leechii larvae.

HWE was divided by LHW to quantify the proportion of cannibal morph. SVL was measured to discern the correlation between predation risk level and body size. Mean SVL was $11.61 \pm 1.47$ and mean HWE/LHW was $0.82 \pm 0.07$.

After predation risk exposure, we maintained larvae another one week without food supplement to observe if any cannibalism occursin each test groups.

\subsection{Statistical analyses}

To analyze data from the three experimentalgroups of larvae, we used nonparametric Kruskal-Wallis 1 way ANOVA test to determine significant changes in the proportion of head size and body size between each group.

And if the groups were significantly independent, we conducted the Jonckeere-Terpstra test to determine the effect of predation risk level which is used for ordered variables. If the Standardized J-T statisticsshowed minus value, higher order for the first group would be valid significantly. Also, we used the Spearman correlation test to reveal a correlation between HWE/LHW and SVL. All tests were significant in alpha range 0.05 and all statistical analyses were performed using SPSS 18.0 (SPSS, Chicago, IL, U.S.A).

\section{RESULTS}

\subsection{Different morphological trait expression by the level of predation risk}

We performed Kruskal-Wallis 1 way ANOVA test and Spearman correlation test to discriminate morphological 
changes in HWE/LHW and SVL. Large HWE/LHW value was shown at the high predation risk and the value was significantly higher than others ( $\mathrm{z}$ values of High VS low $=-3.960$, High VS No cue $=-3.818, \mathrm{p}<0.001)$. In the case of SVL, the high and low risk showed significantly larger than no predation risk ( $\mathrm{z}$ values of Low VS No cue $=-9.677$, High VS No Cue $=-9.984, \mathrm{P}<0.001)$. However, there was no significantchange between the high and low risk.

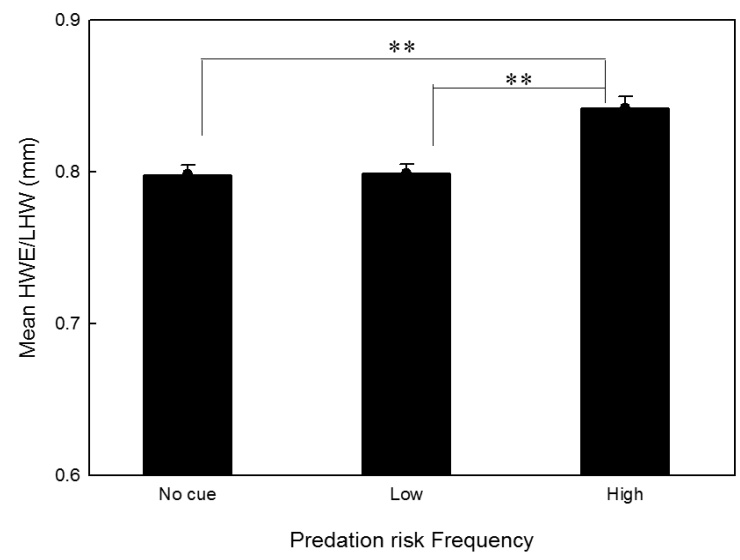

Fig 2. HWE/LHW changes according to level of predation risk $(* * \mathrm{p}<0.001)$

\subsection{Mortality and cannibalism rate by the level of predation risk}

We investigated the mortality of larval salamanders at the first week after the hatching. Mortality rate in the high predation risk condition was the highest, while the no predation risk group had the lowest mortality rate (Fig. 4).

We also expected the cannibalism would occurin each experiment groups, we could not observe any.

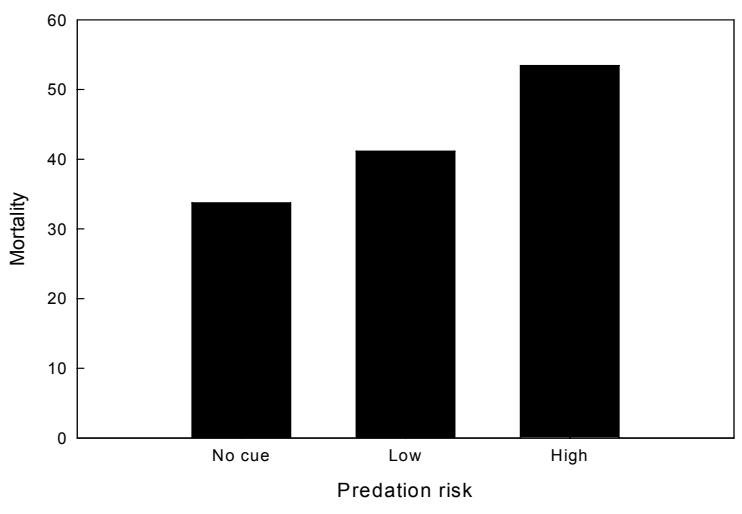

Fig 4. Mortality rate at the first week after the hatching according to the level of predation risk $(n=184)$
We also used the Jonckeere-Terpstra test to determine the effects of predation level increscent. The standardizedJ-T statistic showed minus values in HWE/LHW and SVL (HWE/LHW $=-4.504$, SVL = -7.813). Thus higher order for the first group to third group which had high predation risk to no predation risk treatment had valid significantly. In other words, HWE/LHW and SVL had larger value as the predation risk increase.

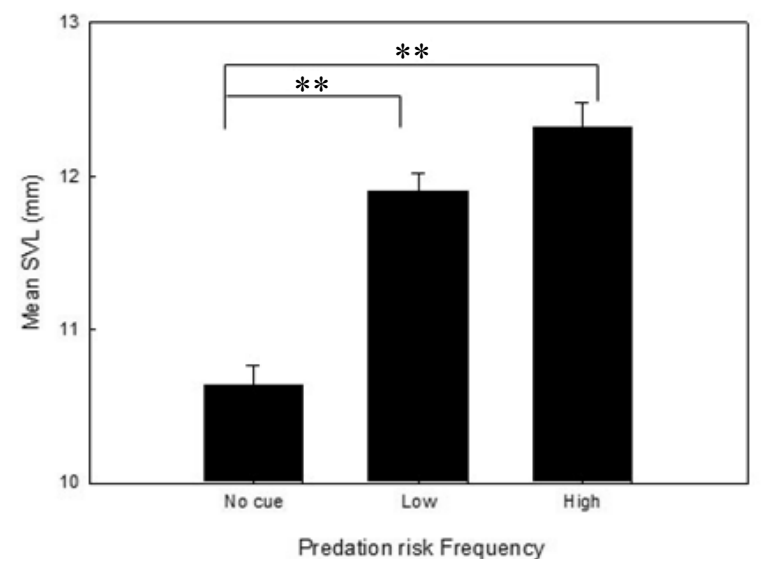

Fig 3. SVL changes according to predation risk frequency.

\section{DISCUSSION}

The present study documented significant cannibalistic polyphenism in larval Korean salamander by the level of predation risk. The results indicate that the cannibal morph of $H$. leechii was induced by the level of the predation risk.

A few studies have investigated larval amphibian's plasticity and polyphenism. Larval newt, Triturus, is induced to the broaden head morph in an environment containing predatory dragonfly, though the broadened head was not for cannibalism but for the prey that are readily encountered from their refuge (Van Buskirk and Schmidt, 2000). In the case of Spade foot toad, their tadpoles have two different phenotypes. One is a carnivore phenotype that preys on shrimps or conspecifics, and which displays rapid growth. The other is an omnivore phenotype, which preys on detritus and slowly grows and matures. The toads display a similar phenotype at birth, but the phenotypes can be changed by environmental circumstances like pond longevity, hormonal-thyroxine changes (Pfenning, 1992), density, temperature, food-type, and substrate (Storz, 2009). Different myodevelopment alsocan occur 
according to phenotypes along the developmental stage (Storz, 2009).

In the case of salamanders, the cannibal morph of $H$. retardatus can be induced by the presence of similar-sized heterospecific larvae in comparison to the same density with conspecifics, and it can also be induced by the higher density with mixed siblings (Michimae and Wakahara, 2002).

The aforementioned studies were conducted by providing food to larval amphibians. However, our study had a limitation in terms of larval growth after feeding. Instead of providing food to test animal, we focused on the polyphenism at the early developmental stage by the level of predation risk as an environmental variable. Our results showed that head proportion, HWE/LHW, and SVL were increased along with the level of predation risk. Under the constant risk treatment, large body size of larval amphibian indicates that increased investment in defenses from the predation and entails a delayed metamorphosis at a larger size (Laurila et al., 2004). Thus, enlarged SVL of larval Korean salamander at firstweek after the hatching with increasing predation risk could be one of the survival tactics used to effectively avoid predation risk. Increasing head size proportion alsocould be of benefit in the consumption of other larvae that are more nutritious than other food resources; by doing so, they could grow faster and reach metamorphosis sooner (Wakahara, 1997) to reduce the predation risk. Induction of the cannibal morph may preclude cannibalism between larval populations. However, there was no significant change between the absence of chemical cue, and the low risk condition and we also could not observe any cannibalism at each experimental group. We suppose if the cannibal morph is induced easily by the small predation risk, they might not succeed in breeding due to large costs like severe injury, parasites, or pathogens (Polis, 1981), the killing of relatives, and diminishing the indirect component of their inclusive fitness (Pfenning, 1997). Therefore, the observed insignificance between the absence of predation risk and low risk could be natural for the survival of larval Korean salamander populations.

Finally, the results of mortality rates of after treatment ofthe test animals showed increased mortality rate as the predation risk intensified. From these results, we assume that higher mortality at high predation risk could be the lack of stockpiled polysacharide due to the energy use by larval salamanders required to enlarge their SVL and HWE/LHW at the early developmental stage. Therefore larvae which consume energy faster than others for enlargement of body would need to forage earlier, and, if food resource were scarce, could ingest their conspecifics as a means of survival though there was no actual cannibalisim in our laboratory test system.

In this study, we tested the hypothesis that the level of predation risk can induce cannibalistic phenotype under limited circumstance. This results showed that predation risk can emerge trophic-(cannibal morph larvae and non-cannibal morph larvae) and predator induced defense dimorphism at the same time. However, our study is lack of identification of proximate and functional causesof larval Korean salamander's polyphenism, thus further study should follow at this point of view.

\section{Acknowledgements}

This paper was supported by the Sahmyook University Research Fund.

\section{References}

Altwegg, R and Reyer, HU (2003). Patterns of natural selections and evolution of species, Science, 294, pp. 321-326.

Berven, KA (1990). Factors affection population fluctuations in larval and adult stages of the wood frog (Rana sylvatica), Ethology, 7, pp. 1599-1608.

Brown, GE, Rive, AC and Ferrari, MCO (2006). The dynamic nature of antipredator behavior: prey fish integrate threat-sensitive antipredator responses within background levels of predation risk, Behav. Ecol. Sociobiol., 61, pp. 9-16.

Clark, CW (1994). Antipredator behaviour and the asset protection principle, Behav. Ecol., 5, pp. 159-170.

Crump, ML (1992). Cannibalism in amphibians, Cannibalism: Ecology and Evolution among Diverse Taxa, MA Elgar and BJ Crespi (eds.). Oxford University Press, Oxford, pp. 256-276.

Ferrari, MCO and Chivers, DP (2008). Cultural learning of predators in mixed species assemblages: the effects of tutor-to-obsever ratio, Anim Behav., 75, pp. 19211925.

Ferrari, MCO and Chivers, DP (2009). Temporal variability, threat-sensitivity and conflicting information about the nature of risk: understanding the dynamics of tadpole antipredator behaviour, Anim. Behav., 78, 
pp. 11-16.

Houston, AI, McNamara, J and Huthcinson, JMC (1993). General results concerning the trade-off between gaining energy and avoiding predation, Philos. Trans. R. Soc. Lond. B., 341, pp. 375-397.

Hwang, JH and Chung H (2010). The polyphenism by the level of predation risk and habitat in larval salamander, Hynobius leechii, Kor. J. Env Eco., 24, pp. 744-750.

Jackson, ME and Semlitsch, RD (1993). Paedomorphosis in the salamander Ambystoma talpoideum: effectsof a fish predator, Ecology, 74, pp. 342-250.

Kats, KB and Dill, KM (1998). The scent of death: chemosensory assessment of predation risk by prey animals, Ecoscience, 5, pp. 361-394.

Laurila, A, Jarvi- Laturi, M, Pakkasmaa, S and Merila, J (2004). Temporal variation in predation risk: stagedependency, graded responses and fitness costs in tadpole antipredator dfences. Oikos, 107, pp. 90-99.

Lima, SL and Dill, LM (1990). Behavioral decisions made under the risk of predation: a review and prospectus, Canadian J. of Zoology, 68, pp. 619-640.

Lima, SL and Bednekoff, PA (1999). Temporal variation in danger dfrives antipredator behavior: the predation risk allocation hypothesis. Am. Nat., 153, pp. 649-659.

Merilia, J and Crnokrak, P (2001). Comparison of marker gene and quantitative genetic differentiation among popultations, J. Evol. Biol., 14, pp. 892-903.

Michimae, M and Wakahara, M (2001). Factors which affect the occurrence of cannibalism and the broad headed "cannibal" morph in larvae of the salamander Hynobius retardatus, Behav. Ecol. Sociobiol., 50, pp. 339-345.

Michimae, M and Wakahara, M (2002). A tadpole-induced polyphenism in the salamander Hynobius retardatus, Evolution., 56(10), pp. 2029-2038.

Nishihara, A (1996). Effects of density on growth of head size in larvae of the salamander Hynobius retardatus, Copeia, 1996(2), pp. 478-483.

Park, SR, Jeong, JY and Park, DS (2005). Cannibalism in the Korean salamander (hynobius leechii: Hynobiidae, caudata, amphibia) larvae, Integrative Biosciences, 9, pp. 13-18.

Pfenning, DW (1992). Proximate and functional causes of polyphenism in an anuran tadpole, Funct. Ecol., 6, pp. 167-174.

Pfenning, DW (1997). Kinship and cannibalism, Bioscience, 47(10), pp. 667-675.

Polis, GA (1981). The evolution and dynamics of intraspecific predation, Anny. Rev. Ecol. Syst., 12, pp. 225-251.

Scott, DE (1994). The effect of larval density on adult demographic traits in Ambystoma opacum, Ecol., 75, pp. 1383-1396.

Sih, A and Mccarthy, TM (2002). Prey responses to pulses of risk and safety: testing the risk allocation hypothesis, Anim. Behav., 63, pp. 437-443.

Sih, A and Moore, RD (1993). Delayed hatching of salamander eggs in response to enhanced larval predation risk, Am. Nat., 142, pp. 947-960.

Smith, DC (1987). Adult recruitment in chorus frogs: effects of size and date at metamorphosis, Ecology, 68 , pp. $344-350$.

Stemberger, SS and Gilbert, JJ (1987). Multiple-species induction of morphological defenses in the rotifer Keratella testudo, Ecology, 68, pp. 370-378.

Turner, AM, Bernot, RJ, and Boss, CM (2000). Chemical cues modify species interactions; the ecological consequences of predator avoidance by freshwater sails, Oikos, 88, pp. 148-158.

Tollrian, R and Harvell, CD (1999). The ecology and evolution of inducible defenses, Princeton Univ Press, Princeton, New Jersey, USA.

Van Buskirk, J and Schmidt, BR (2000). Predator-induced phenotypic plasticity in larval newts: trade-offs, selection, and variation in nature, Ecology, 81, pp. 3009-3028.

Van Buskirk, J, Muller, C, Portmann, A and Surbeck, M (2002). A test of the risk allocation hypothesis: tadpole responses to temporal change in predation risk, Behavioral Ecology, 13(4), pp. 526-530.

Van Buskirk, J and Arioloi, M (2002). Dosage response of an induced defense: How sensitive are tadpoles to predation risk?, Ecology, 83(6), pp.1580-1585.

Wakahara, M (1995). Cannibalism and the resulting dimorphism in larvae of a salamander Hynobius.

retardatus, inhabited in Hokkaido, Japan Zool. Sci., 12, pp. 467-473.

Wakahara, M (1997). Kin recognition among intact and blinded, mixed-sibling larvae of a cannibalistic salamander Hynobius retardatus, Zool. Sci., 14, pp. 893-899.

Wellborn, GA, Skelly, DK and Werner EE (1996). Mechanisms creating community structure across a freshwater habitat gradient, Annu. Rev. Ecol. Syst., 27, pp. 337-363.

West-Eberhard, MJ (1992). Behavior and evolution, Molds, Molecules and Metazoans: Growing Points in Evolutionary Biology, Grant PR and H. S. Horn (eds.), Princeton University Press, Princeton, pp. 55-75. 
West-Eberhard, MJ (1989). Phenotypic plasticity and the origins of diversity, Ann. Rev., 20, pp. 249-278.

Wiseden, BD (2000). Olfactory assessment of predation risk in the aquatic environment, Phil. Trans. R. Soc. Lond. B., 355, pp. 1205-1208.
논문접수일 : 2013년 04월 18일

심사의뢰일 : 2013년 04월 29일

심사완료일 : 2013년 08월 09일 